RESEARCH PAPER RP1564

Part of Journal of Research of the National Bureau of Standards, Volume 31, November 1943

\title{
REPORT ON THE SYSTEMS LEAD OXIDE-ALUMINA AND LEAD OXIDE-ALUMINA-SILICA
}

\author{
By R. F. Geller and E. N. Bunting
}

\begin{abstract}
Phase relations were studied for those portions of the binary and the ternary systems containing over 50 percent of $\mathrm{PbO}$. It is reasonably certain that the binary system contains the compound $\mathrm{PbO} \cdot \mathrm{Al}_{2} \mathrm{O}_{3}$. In the ternary system $3 \mathrm{com}-$ pounds $\left(8 \mathrm{PbO} \cdot \mathrm{Al}_{2} \mathrm{O}_{3} .4 \mathrm{SiO}_{2}, 4 \mathrm{PbO} \cdot \mathrm{Al}_{2} \mathrm{O}_{3} .2 \mathrm{SiO}_{2}\right.$, and $\left.6 \mathrm{PbO} \cdot \mathrm{Al}_{2} \mathrm{O}_{3} \cdot 6 \mathrm{SiO}_{2}\right)$ were identified, 4 others were indicated by optical and $\mathrm{X}$-ray properties, and 10 quintuple points, which include 6 eutectics, were established. Also, $\mathrm{Al}_{2} \mathrm{O}_{3}$ (99.9 plus purity) was observed to melt at $2,035^{\circ} \mathrm{C}$.
\end{abstract}

\section{CONTENTS}

1. Materials

2. Test methods

III. The system $\mathrm{PbO}-\mathrm{Al}_{2} \mathrm{O}_{3}$

IV.

1. The silica, mullite, and corundum fields

2 . The fields of $\mathrm{PbO}$ and its binary compounds.... 263

3. Fields of the ternary compounds

4. Ternary compounds of undetermined composition

5. Compositions as glasses.....

V. Summary

\section{INTRODUCTION}

This report is published in order that the limited information given may be available for use now rather than to wait until more peaceful times make it possible to complete the study.

Because of extremely slow crystallization rates and other unfavorable characteristics of compositions over the greater portion of these two systems, the progress of the work has been very slow. Three years were required to obtain the data presented at this time, and there is every indication that experimental difficulties will increase as the explored area is extended toward the $\mathrm{Al}_{2} \mathrm{O}_{3}-\mathrm{SiO}_{2}$ side of the diagram. The study is a part of the broad survey of systems containing $\mathrm{PbO}$ that has been in progress since $1932 .^{1}$

The $\mathrm{PbO}-\mathrm{SiO}_{2}$ system (see footnote 1 ) and the system $\mathrm{Al}_{2} \mathrm{O}_{3}-\mathrm{SiO}_{2}{ }^{2}$

1 R. F. Geller, A. S. Creamer, and E. N. Bunting, J. Research NBS 13, 237 (1934) RP705; R. F. Geller
and E. N. Bunting, J. Research NBS 17, 277 (1936) RP911; 18, 585 (1937) RP995; 23, 275 (1939) RP1231. 2 N. L. Bowen and J. W. Greig, J. Am. Ceram. Soc. 7, 238 (1924); J. Wash. Acad. Sci. 14, 183 (1924). 
have been investigated. A limited study of the reaction $\mathrm{PbO} \rightleftarrows \mathrm{Pb}_{3} \mathrm{O}_{4}$ was made in connection with this investigation, and the report was published recently. ${ }^{3}$

\section{EXPERIMENTAL PROCEDURE}

\section{MATERIALS}

For compositions prepared directly by fusion, the end members were (a) sublimed litharge containing 0.02 percent of total detected impurities; (b) $\mathrm{Al}_{2} \mathrm{O}_{3}$ prepared by converting aluminum metal of 99.95 percent purity to the nitrate and heating at $1,200^{\circ} \mathrm{C}$ to form the $\mathrm{Al}_{2} \mathrm{O}_{3}$; and (c) pulverized quartz containing 0.02 percent of nonvolatile residue on evaporation with $\mathrm{HF}$ and $\mathrm{H}_{2} \mathrm{SO}_{4}$.

After fusion in platinum, using an electrically heated furnace, the various melts were analyzed chemically (by A. S. Creamer).

When it was necessary to heat specimens at temperatures in excess of about $950^{\circ} \mathrm{C}$, the volatilization of $\mathrm{PbO}$ became noticeable, and this tendency increased with decrease in the $\mathrm{SiO}_{2}$ content. To avoid the excessive volatilization of $\mathrm{PbO}$ during the preparation of melts containing little or no $\mathrm{SiO}_{2}$, a number of compositions were made by coprecipitation prior to fusion, of a nitric acid solution of the litharge already described and reagent quality $\mathrm{Al}\left(\mathrm{NO}_{3}\right)_{3} \cdot 9 \mathrm{H}_{2} \mathrm{O}$ in the presence of silica gel of 99.96 percent purity.

For the determination of the melting point of $\mathrm{Al}_{2} \mathrm{O}_{3}$, a sample of the oxide was prepared by dissolving aluminum metal of over 99.98 percent purity ${ }^{4}$ with reagent quality $\mathrm{HNO}_{3}$ and igniting at $1,100^{\circ} \mathrm{C}$. All reactions were carried out in platinum.

\section{TEST METHODS}

Thermal studies were made by the usual quenching method, using precrystallized samples, of which portions were heated at successively higher temperatures until liquidus was obtained. The specimens for crystallization and for quenching were contained in platinum foil, and it was customary to hold the specimen at least overnight before each quench. The quenching studies were supplemented, in a few cases, with heating curves by the differential thermocouple method. All heatings were made in electrically heated furnaces, and the $\mathrm{Pt}$ to $\mathrm{Pt}-\mathrm{Rh}$ thermocouples were calibrated by observing the melting temperature of $\mathrm{KCl}\left(770.3^{\circ} \mathrm{C}\right)$ and $\mathrm{K}_{2} \mathrm{SO}_{4}\left(1,069.1^{\circ} \mathrm{C}\right)$. Unless otherwise noted in the text or the tables, critical temperatures may be considered accurate to $\pm 2^{\circ} \mathrm{C}$.

Compositions containing over about 90 percent of $\mathrm{PbO}$ could be crystallized by holding at a suitable temperature for several hours, but this holding time increased greatly with decrease in $\mathrm{PbO}$ content. For melts containing 50 to 60 percent of $\mathrm{PbO}$, for example, it was not unusual to develop only partial crystallization after treatments of from 1 to 2 months' duration.

Examination of treated specimens with the petrographic microscope was made in all cases. The results were verified, when necessary, with X-ray diffraction patterns made and interpreted by H. F. McMurdie. Details of these examination methods have been described. ${ }^{5}$

${ }^{3}$ NBS Tech. News Bul. 315, p. 52 (July 1943)

Furnished by James I. Hoffman, and described by him and G. E. F. Lundell in J. Research NBS 18, (1937) RP957.

B R. F. Geller and E. N. Bunting, J. Research NBS 23, 278 (1939) RP1231. 
The $\mathrm{Al}_{2} \mathrm{O}_{3}$ melting point was observed with an optical pyrometer while the specimen was resting on an iridium pedestal in an electrically heated furnace. ${ }^{6}$ The pyrometer calibration was certified to $\pm 10^{\circ} \mathrm{C}$ by the Pyrometry Section of this Bureau.

\section{THE SYSTEM PbO- $\mathrm{Al}_{2} \mathrm{O}_{3}$}

The existence of a eutectic at about $865^{\circ} \mathrm{C}$ and 94 percent of $\mathrm{PbO}$ between $\mathrm{PbO}$ and a compound of $\mathrm{PbO}$ and $\mathrm{Al}_{2} \mathrm{O}_{3}$ seems reasonably certain (fig. 1) and the data suggest the compound $\mathrm{PbO} \cdot \mathrm{Al}_{2} \mathrm{O}_{3}$ for two reasons: (a) the absence of a break in the heating curve of the compound composition at about $865^{\circ} \mathrm{C}$. This break occurred con-

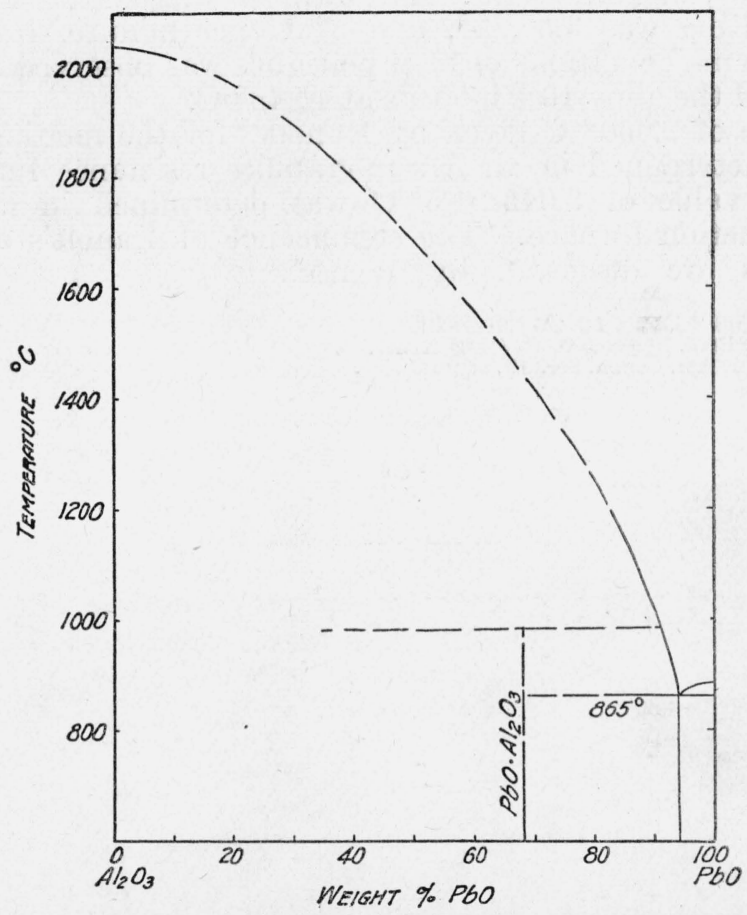

Figure 1.-The system $\mathrm{PbO}-\mathrm{Al}_{2} \mathrm{O}_{3}$

sistently for the compositions higher in $\mathrm{PbO}$ than the $1: 1$ ratio and is believed to show the $\mathrm{PbO} \cdot \mathrm{Al}_{2} \mathrm{O}_{3}-\mathrm{PbO}$ eutectic temperature (table 1); and (b) the most nearly complete crystallization to one phase was obtained with the $\mathrm{PbO}$ and $\mathrm{Al}_{2} \mathrm{O}_{3}$ in equimolar ratio (table 1). Beyond this composition, in the region of higher $\mathrm{Al}_{2} \mathrm{O}_{3}$ content, the true phase relations are largely conjectural, and were not investigated further because of the extremely rapid volatilization of $\mathrm{PbO}$ during both the preparation of melts and the crystallization trials.

The phase assumed to be $\mathrm{PbO} \cdot \mathrm{Al}_{2} \mathrm{O}_{3}{ }^{7}$ is uniaxial negative, has indices of refraction $\epsilon 1.85, \omega 1.91$, crystallizes in platy form, and the diffraction data are given in table 2 . The data summarized in table 1

6 R. F. Geller, J. Research NBS 27, 555 (1941) RP1443.

7 When references are made in this report to the compound $\mathrm{PbO} \cdot \mathrm{Al}_{2} \mathrm{O}_{3}$, it should be remembered that its existence has not been definitely established. 
indicate that it breaks down rapidly at about $1,000^{\circ} \mathrm{C}$ to form beta $\mathrm{Al}_{2} \mathrm{O}_{3}$ and liquid. Whether this "break down" is a true incongruent melting, or a decomposition accelerated at $970^{\circ}$ to $1,000^{\circ} \mathrm{C}$ and resulting from volatilization of $\mathrm{PbO}$, is not clear. The latter explanation seems plausible in view of the heating-curve results on melt 5, which showed a drift, beginning at about $970^{\circ} \mathrm{C}$, rather than a definite break.

Solid solution in this system is indicated. In some melts the indices of refraction of the $\mathrm{PbO} \cdot \mathrm{Al}_{2} \mathrm{O}_{3}$ varied, being slightly lower. Also, in some cases the alpha alumina had indices of refraction above 1.765 probably because of $\mathrm{PbO}$ dissolved in the crystal.

The $\mathrm{Al}_{2} \mathrm{O}_{3}$ sample was observed, in three tests, to melt sharply at $2,040^{\circ}, 2,030^{\circ}$, and $2,030^{\circ} \mathrm{C}$. The rate of temperature rise at the time of melting was $3.5^{\circ}, 2^{\circ}$, and $5^{\circ} \mathrm{C}$ per minute, respectively. Under the same conditions of test, platinum was observed to melt at $1,770^{\circ} \mathrm{C}$ and the alloy $10 \mathrm{Rh}-90 \mathrm{Pt}$ at $1,845^{\circ} \mathrm{C}$.

The value of $2,050^{\circ} \mathrm{C}$ given by Kanolt ${ }^{8}$ for the melting point of $\mathrm{Al}_{2} \mathrm{O}_{3}$ was determined in an Arsem-graphite resistance furnace, and Bunting's ${ }^{9}$ value of $2,045 \pm 5^{\circ} \mathrm{C}$ was determined in a high-frequency induction furnace. The significance of Kanolt's and Bunting's values are discussed by Wensel. ${ }^{10}$

${ }^{8}$ C. W. Kanolt, BS Sci. Pap. 10, 295 (1914) S212.

E. N. Bunting, BS J. Research 6, 947 (1931) RP317.

10 H. T. Wensel, J. Am. Ceram. Soc. 19, 81 (1936). 
TABLE 1.-Quenching tests, heating-curve results, and $X$-ray examinations for the $\mathrm{PbO}-\mathrm{Al}_{2} \mathrm{O}_{3}$ system

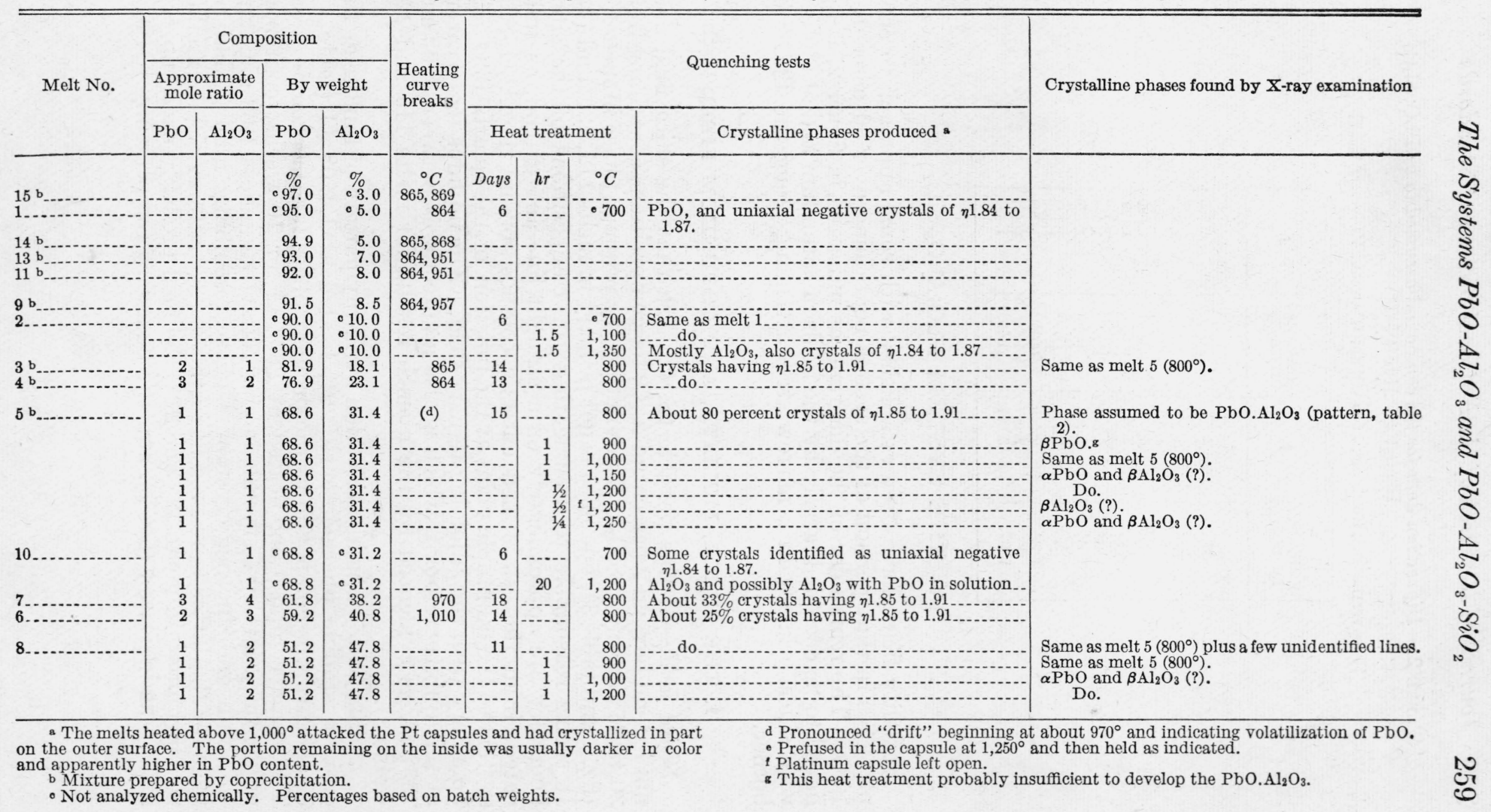


TABLE 2.-Diffraction data for the compound assumed to be $\mathrm{PbO}^{-\mathrm{Al}_{2} \mathrm{O}_{3}}$

(by H. F. McMurdie)

[ $V S=$ very strong; $S=$ strong; $M=$ medium; $W=$ weak; $V W=$ very weak]

\begin{tabular}{|c|c|c|c|}
\hline $\begin{array}{l}\text { Estimated } \\
\text { intensity }\end{array}$ & $d$ & $\begin{array}{l}\text { Estimated } \\
\text { intensity }\end{array}$ & $d$ \\
\hline $\begin{array}{c}M \\
S \\
W \\
M \\
V S \\
M \\
M \\
M \\
V W \\
V W \\
S \\
W \\
W W \\
W \\
W W\end{array}$ & $\begin{array}{l}A \\
4.66 \\
4.43 \\
4.22 \\
4.05 \\
3.08 \\
2.621 \\
2.507 \\
2.367 \\
2.303 \\
2.221 \\
2.165 \\
2.140 \\
2.097 \\
2.009\end{array}$ & $\begin{array}{c}M \\
M \\
M \\
W \\
M \\
V W \\
V W \\
V W \\
V W \\
W \\
W \\
W \\
V W \\
W \\
W \\
W\end{array}$ & 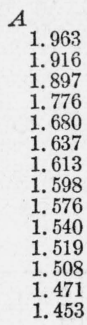 \\
\hline
\end{tabular}

\section{THE SYSTEM PbO- $\mathrm{Al}_{2} \mathrm{O}_{3}-\mathrm{SiO}_{2}$}

Stability fields have been established with some approach to completeness in that portion of the system containing over 80 percent of $\mathrm{PbO}$. The remainder of the diagram, as indicated in figure 2 , is believed to be occupied largely by the fields of corundum and of mullite, with silica primary in a narrow strip extending along the $\mathrm{PbO}-\mathrm{SiO}_{2}$ border.

\section{THE SILICA, MULLITE, AND CORUNDUM FIELDS}

Silica field.-It was possible to establish that the silica field does not extend beyond 2 percent of $\mathrm{Al}_{2} \mathrm{O}_{3}$ for compositions containing from 30 to 35 percent of $\mathrm{SiO}_{2}$. Tridymite is the primary phase in melt 158 (fig. 2 and table 3), but silica is not primary in melts 112, 130, and 143 . It seems reasonable to assume that the compositions of the silica boundary are approximately on a straight line and extend, as indicated, from the established eutectic composition in the $\mathrm{Al}_{2} \mathrm{O}_{3}-\mathrm{SiO}_{2}$ system to the quintuple point at the junction of the quartz- $\mathrm{PbO} \cdot \mathrm{SiO}_{2}$ boundary with the adjoining ternary field. The liquidus temperature at this quintuple point, which is also a eutectic, is between $720^{\circ}$ and $725^{\circ} \mathrm{C}$, as evidenced by the quench results for melts 113 and 143 (table 3).

Mullite field.-The identification by X-ray pattern of mullite as the only crystalline phase in melt 201 , heated at $1,450^{\circ} \mathrm{C}$ (table 3 ), establishes this compound as the primary phase for that composition. The same composition, heated at $880^{\circ} \mathrm{C}$ for 10 weeks, contained unidentified lath-like crystals having refractive indices $1.69 \mathrm{max}$ and $1.67 \mathrm{~min}$ and another crystalline phase resembling mullite, but no lines for the latter were present in the X-ray pattern. Since mullite was not found in melts 128 and 204, the field probably ends approximately as indicated (fig. 2), and the boundary temperatures may be 
expected to decrease toward the tridymite field. This assumption is supported by the fact that the liquidus for melt 128 is above $1,200^{\circ} \mathrm{C}$, and for melt 204 it is about $1,025^{\circ} \mathrm{C}$. As the data in table 3 show, the liquidus of melt 201 is above $1,450^{\circ} \mathrm{C}$.

Corundum field.-The presentation of the corundum field, as shown in figure 2, is based in part on the data in table 1 and in part on the $\mathrm{X}$-ray identification of alpha alumina as the primary phase in melts 258,260 , and 273 (table 3 ). Furthermore, the X-ray data and the results of quenching tests support the assumption that $\mathrm{PbO} \cdot \mathrm{Al}_{2} \mathrm{O}_{3}$,

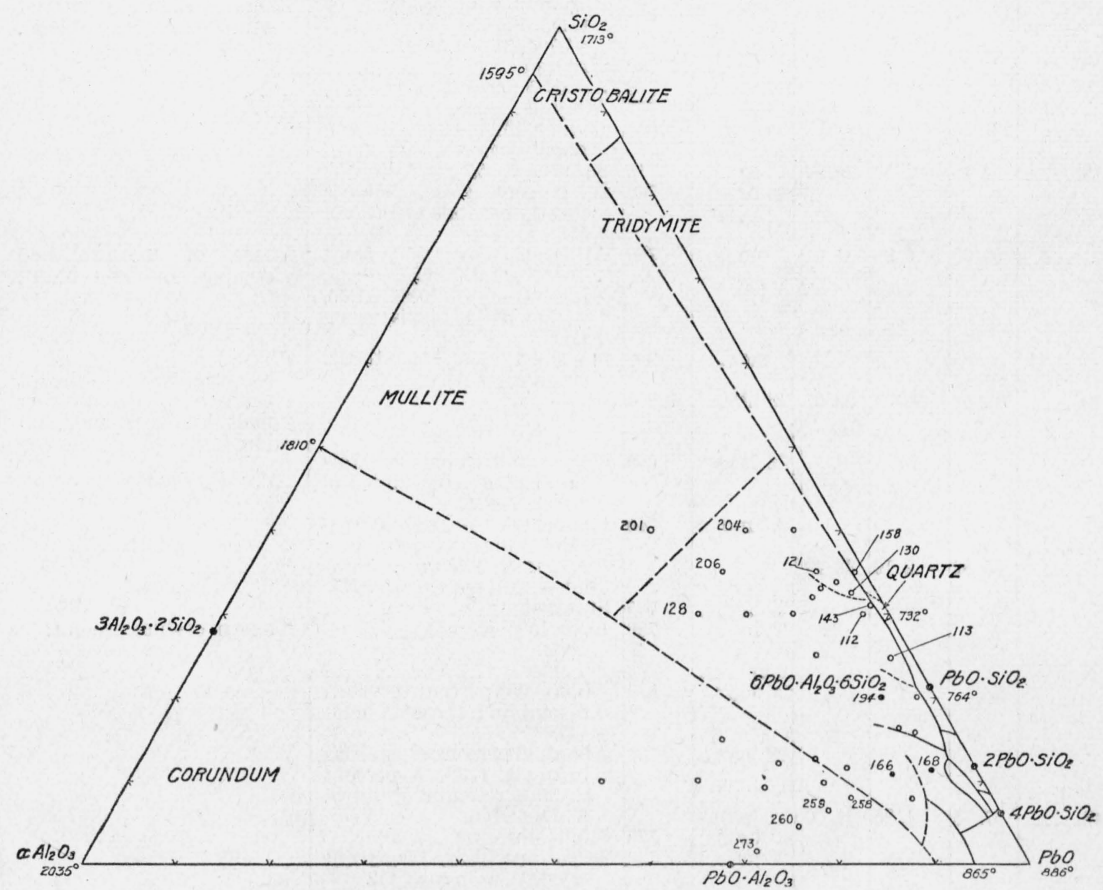

Figure 2.-The system $\mathrm{PbO}-\mathrm{Al}_{2} \mathrm{O}_{3}-\mathrm{SiO}_{2}$.

The open circles indicate most of those compositions investigated containing less than about 80 percent of $\mathrm{PbO}$. The filled circles indicate the compound compositions. The value of $1,595^{\circ} \mathrm{C}$ for the $\mathrm{Al}_{2} \mathrm{O}_{3}-\mathrm{SiO}_{2}$ eutectic is taken from J. F. Schairer, J. Am. Ceram. Soc. 25,241 (footnote 57) (1942).

and also the unidentified phase in melts $258,259,260$, and 273 , melt incongruently to form corundum and glass. The corundum boundary, as drawn in figure 2, extends from 50 percent of $\mathrm{Al}_{2} \mathrm{O}_{3}$ in the $\mathrm{Al}_{2} \mathrm{O}_{3}-\mathrm{SiO}_{2}$ system to 10 percent of $\mathrm{Al}_{2} \mathrm{O}_{3}$ in the $\mathrm{PbO}-\mathrm{Al}_{2} \mathrm{O}_{3}$ system. Temperatures at the quintuple points along this curve have not been determined, and the only fields of established compounds bordering on the corundum field are those of mullite and of $\mathrm{PbO} \cdot \mathrm{Al}_{2} \mathrm{O}_{3}$. 
TABLE 3.-Results of crystallization and quenching tests and X-ray examinations on compositions identified by their Melt Numbers in figure 2

[Portions of the precrystallized samples were used in all cases for specimens quenched after heat treatments of 5 days or less duration]

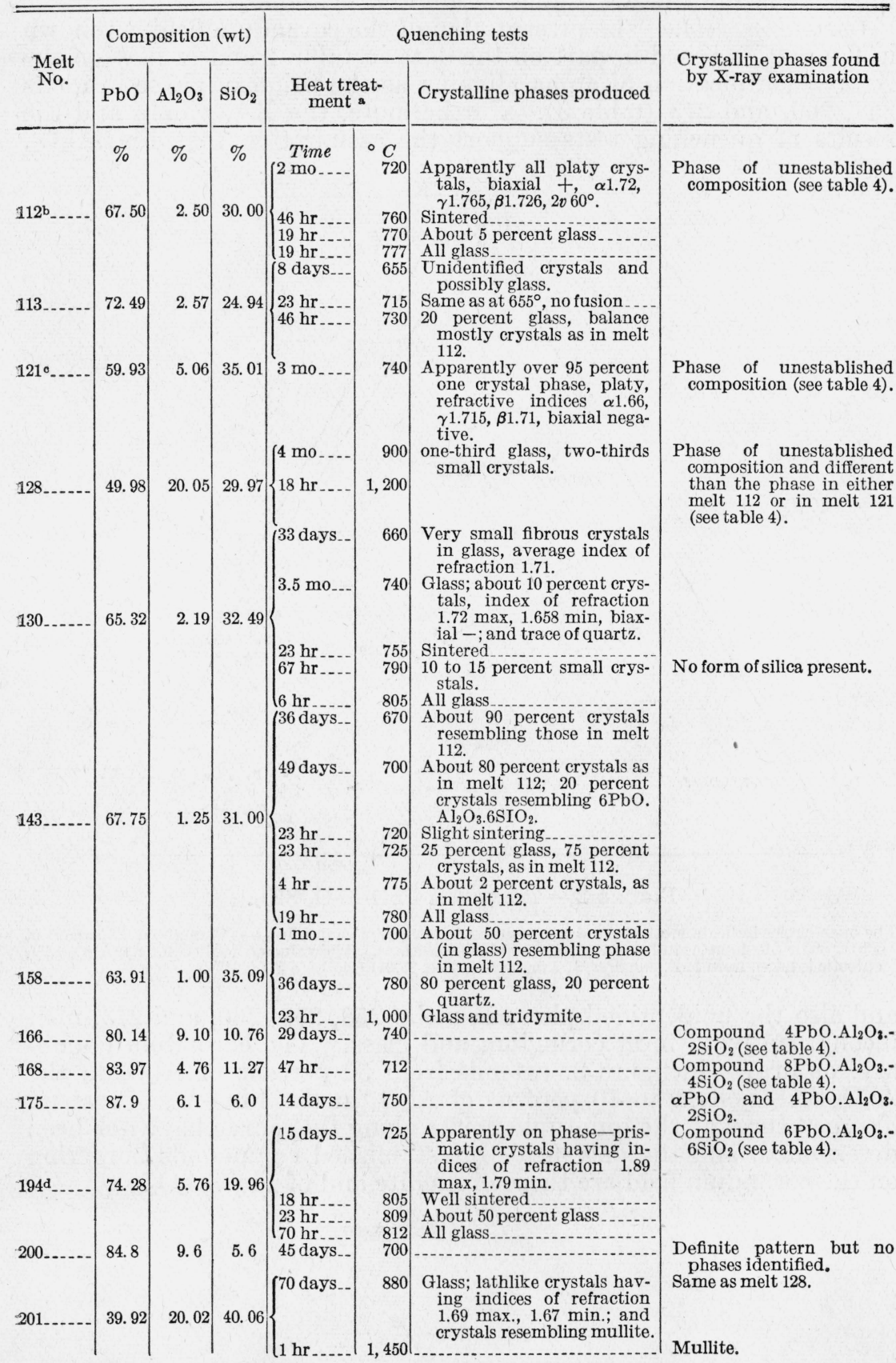

See footnotes at end of table. 
TABLE 3.-Results of crystallization and quenching tests and $X$-ray examinations on compositions idenıified by their Melt Numbers in figure 2

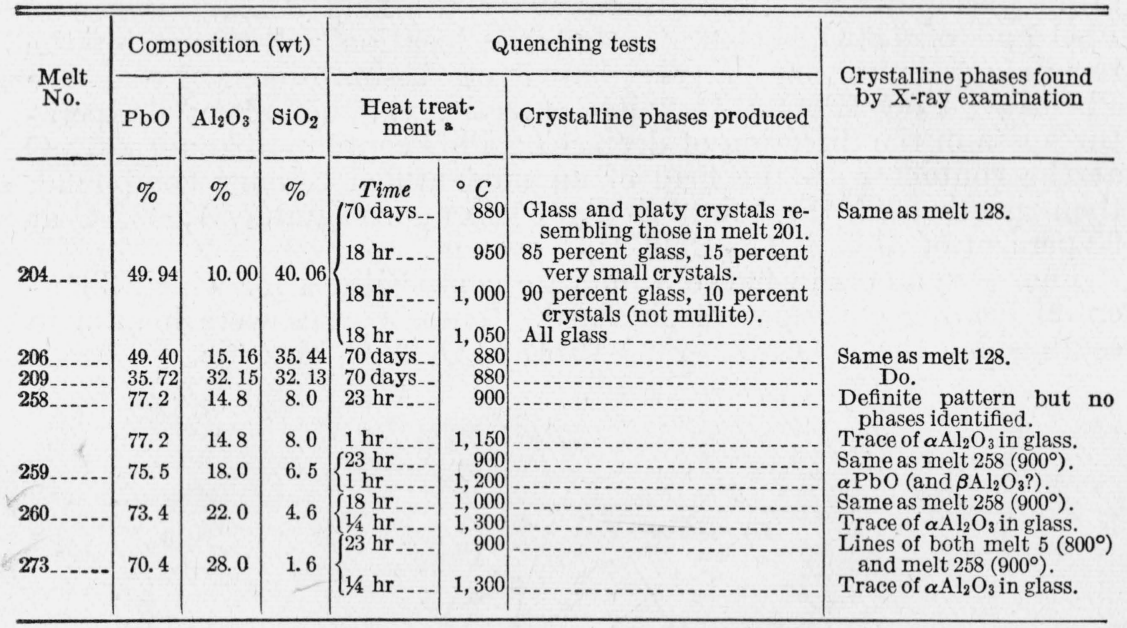

a For the heat treatments involving several weeks or months, the indicated temperatures were held to $\pm 20^{\circ} \mathrm{C}$. For the shorter treatments, the temperatures were held to $\pm 0.5^{\circ} \mathrm{C}$.

b This composition approximates the mole ratio $12 \mathrm{PbO}: \mathrm{Al}_{2} \mathrm{O}_{3}: 20 \mathrm{SiO}_{2}$.

- This composition approximates the mole ratio $5 \mathrm{PbO}: \mathrm{Al}_{2} \mathrm{O}_{3}: 10 \mathrm{SiO}_{2}$.

d This composition approximates the compound composition $6 \mathrm{PbO}: \mathrm{Al}_{2} \mathrm{O}_{3}: 6 \mathrm{SiO}_{2}$.

\section{THE FIELDS OF PbO AND ITS BINARY COMPOUNDS}

These fields are shown more clearly in figure 3 than in figure 2, except for the area in which $\mathrm{PbO} . \mathrm{SiO}_{2}$ is primary.

Lead metasilicate $\left(\mathrm{PbO} . \mathrm{SiO}_{2}\right)$ field.-Figure 2 shows this as a very narrow field extending from 15.4 to 29.6 weight percent of $\mathrm{SiO}_{2}$, in the $\mathrm{PbO}-\mathrm{SiO}_{2}$ system, to a maximum $\mathrm{Al}_{2} \mathrm{O}_{3}$ content of 1.7 percent at about the $\mathrm{PbO} \cdot \mathrm{SiO}_{2}-6 \mathrm{PbO} \cdot \mathrm{Al}_{2} \mathrm{O}_{3} \cdot 6 \mathrm{SiO}_{2}$ join.

From the liquidus temperature of $695^{\circ} \mathrm{C}$ at the $\mathrm{PbO} \cdot \mathrm{SiO}_{2}-2 \mathrm{PbO}-$ $\mathrm{SiO}_{2}-6 \mathrm{PbO} \cdot \mathrm{Al}_{2} \mathrm{O}_{3} \cdot 6 \mathrm{SiO}_{2}$ eutectic, the boundary temperatures rise to

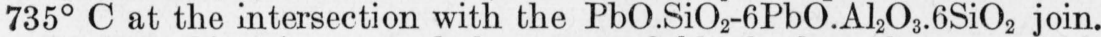

Beyond this join, toward the quartz field, the boundary compositions are believed to be very nearly as indicated, it being relatively simple to establish the composition limits in which the metasilicate is primary. Little is known in detail, however, regarding the boundary temperatures.

Lead orthosilicate $\left(2 \mathrm{PbO} . \mathrm{SiO}_{2}\right)$ field.-This field extends from 8.2 to 15.4 weight percent of $\mathrm{SiO}_{2}$, in the $\mathrm{PbO}-\mathrm{SiO}_{2}$ system, to a maximum $\mathrm{Al}_{2} \mathrm{O}_{3}$ content of 2.3 percent at the $2 \mathrm{PbO} \cdot \mathrm{SiO}_{2}-8 \mathrm{PbO} \cdot \mathrm{Al}_{2} \mathrm{O}_{3} \cdot 4 \mathrm{SiO}_{2}-$ $4 \mathrm{PbO} \cdot \mathrm{Al}_{2} \mathrm{O}_{3} \cdot 2 \mathrm{SiO}_{2}$ quintuple point. The details are shown in figures 3 and 4.

Tetralead silicate $\left(4 \mathrm{PbO} . \mathrm{SiO}_{2}\right)$ field. $-4 \mathrm{PbO} . \mathrm{SiO}_{2}$ is primary in a very small composition area, extending from 6.7 to 8.2 weight percent of $\mathrm{SiO}_{2}$ in the $\mathrm{PbO}-\mathrm{SiO}_{2}$ system, to 1.2 percent of $\mathrm{Al}_{2} \mathrm{O}_{3}$ at the $4 \mathrm{PbO} . \mathrm{SiO}_{2}-$ $8 \mathrm{PbO} . \mathrm{Al}_{2} \mathrm{O}_{3} .4 \mathrm{SiO}_{2}-2 \mathrm{PbO} . \mathrm{SiO}_{2}$ eutectic. The $4 \mathrm{PbO} . \mathrm{SiO}_{2}-8 \mathrm{PbO} . \mathrm{Al}_{2} \mathrm{O}_{3}$.$4 \mathrm{SiO}_{2}$ boundary temperatures rise to $700^{\circ} \mathrm{C}$ at the intersection with the join.

$\mathrm{PbO}$ field.-The boundary of the $\mathrm{PbO}$ field extends from 6.7 weight percent of $\mathrm{PbO}$ in the $\mathrm{PbO}-\mathrm{SiO}_{2}$ system to the $\mathrm{PbO}-4 \mathrm{PbO} \cdot \mathrm{Al}_{2} \mathrm{O}_{3} \cdot 2 \mathrm{SiO}_{2}-$ $\mathrm{PbO} . \mathrm{Al}_{2} \mathrm{O}_{3}$ eutectic (fig. 3), and then rises to $865^{\circ} \mathrm{C}$ at 94 percent of $\mathrm{PbO}$ in the $\mathrm{PbO}-\mathrm{Al}_{2} \mathrm{O}_{3}$ system. 
$\mathrm{PbO} \cdot \mathrm{Al}_{2} \mathrm{O}_{3}$ field.-The limits of this field, and the boundary temperatures, are fairly well established where the field contacts those of $\mathrm{PbO}$ and of $4 \mathrm{PbO} \cdot \mathrm{Al}_{2} \mathrm{O}_{3} \cdot 2 \mathrm{SiO}_{2}$, but the location and nature of the remaining limits are largely based on assumptions. From the $\mathrm{PbO} . \mathrm{Al}_{2} \mathrm{O}_{3}-\mathrm{PbO}-4 \mathrm{PbO} \cdot \mathrm{Al}_{2} \mathrm{O}_{3} .2 \mathrm{SiO}_{2}$ eutectic, the boundary temperatures rise in the direction of decreasing $\mathrm{PbO}$ content to about $837^{\circ} \mathrm{C}$ at the contact with the field of an unidentified ternary compound, then rise through the point $A$ (fig. 3) to approximately $1,000^{\circ} \mathrm{C}$ at 90 percent of $\mathrm{Al}_{2} \mathrm{O}_{3}$ in the $\mathrm{PbO}-\mathrm{Al}_{2} \mathrm{O}_{3}$ system.

The + symbols in figure 3 indicate compositions for which differential heating curves were obtained. These curves were helpful in establishing the $\mathrm{PbO} \cdot \mathrm{Al}_{2} \mathrm{O}_{3}-\mathrm{PbO}-4 \mathrm{PbO} \cdot \mathrm{Al}_{2} \mathrm{O}_{3} \cdot 2 \mathrm{SiO}_{2}$ eutectic.

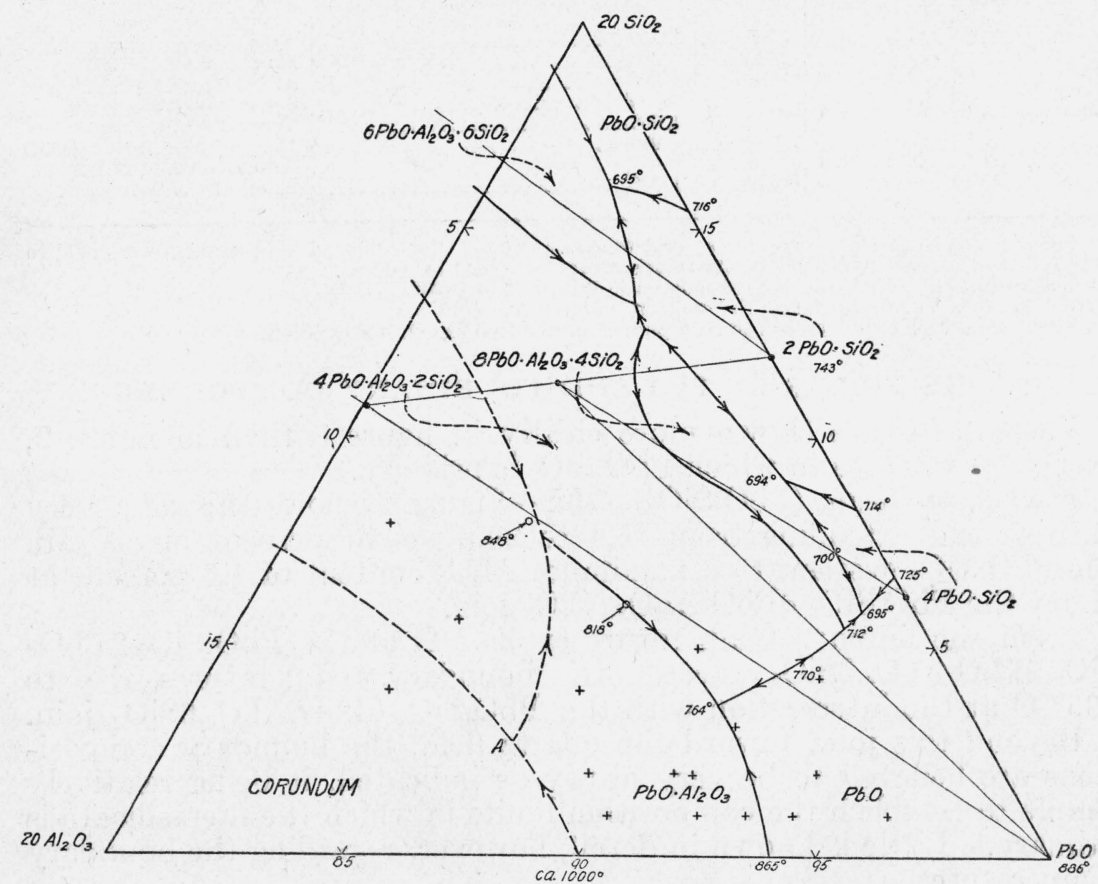

Figure 3.-High $\mathrm{PbO}$ portion of the $\mathrm{PbO}-\mathrm{Al}_{2} \mathrm{O}_{3}-\mathrm{SiO}_{2}$ system.

This portion of the system contains 9 of the 10 established quintuple points and 2 of the 3 established ternary compounds

\section{FIELDS OF THE TERNARY COMPOUNDS}

The composition, melting point, and crystallographic properties of three ternary compounds were determined, but it is practically certain that there are at least four more ternary compounds in the system.

$8 \mathrm{PbO} \cdot \mathrm{Al}_{2} \mathrm{O}_{3} .4 \mathrm{SiO} 2$. - This compound crystallizes as platy laths, characterized by their light-brown appearance when viewed with transmitted light. The refractive indices are $2.08 \max$ and 2.04 min. Optical character was not obtained petrographically.

The X-ray pattern (table 4) is too complex for analysis (H. F. McMurdie). 


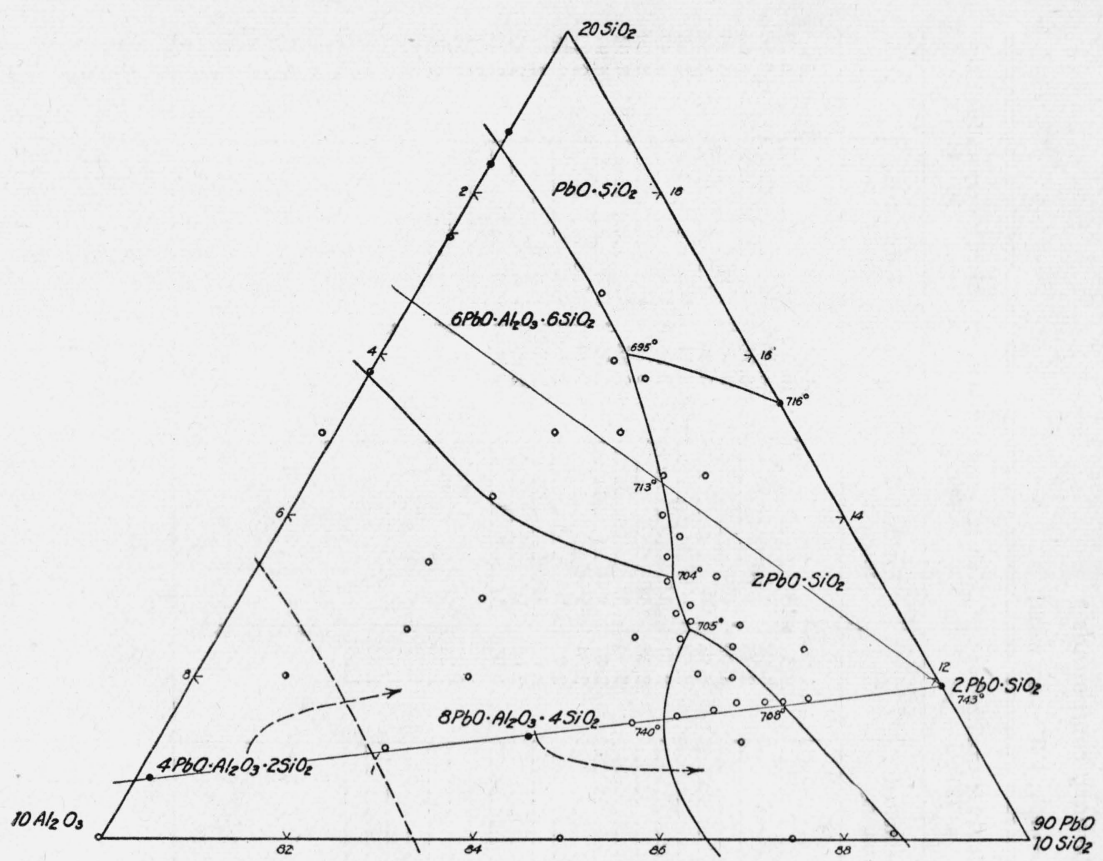

Figure 4.-Detail of the $\mathrm{PbO}-\mathrm{Al}_{2} \mathrm{O}_{3}-\mathrm{SiO}_{2}$ system.

The major portion of the investigation was confined to studies of the compositions, indicated by open circles, in this portion of the system.

$8 \mathrm{PbO} \cdot \mathrm{Al}_{2} \mathrm{O}_{3} \cdot 4 \mathrm{SiO}_{2}$ is the only ternary compound for which the entire stability field is known (fig. 3). Critical boundary temperatures are shown in figures 3 and 4 , and the compositions of the quintuple and eutectic points are given in table 5 . The compound melts incongruently at about $735^{\circ} \pm 5^{\circ} \mathrm{C}$ to form $4 \mathrm{PbO} \cdot \mathrm{Al}_{2} \mathrm{O}_{3} \cdot 2 \mathrm{SiO}_{2}$ and liquid. The reforming of $8 \mathrm{PbO} \cdot \mathrm{Al}_{2} \mathrm{O}_{3} \cdot 4 \mathrm{SiO}_{2}$ is very sluggish (a sample quenched from $745^{\circ} \mathrm{C}$, and which was about 50 percent glass and 50 percent $4 \mathrm{PbO} . \mathrm{Al}_{2} \mathrm{O}_{3} .2 \mathrm{SiO}_{2}$, contained no crystals of $8 \mathrm{PbO} . \mathrm{Al}_{2} \mathrm{O}_{3} .4 \mathrm{SiO}_{2}$ after holding for 47 hours at $720^{\circ} \mathrm{C}$.) $\mathrm{As}$ a result, $4 \mathrm{PbO} . \mathrm{Al}_{2} \mathrm{O}_{3} .2 \mathrm{SiO}_{2}$, which forms during the initial crystallization of a sample, may remain as such; for example, a portion of the original melt was converted to over 90 percent of $8 \mathrm{PbO} \cdot \mathrm{Al}_{2} \mathrm{O}_{3} \cdot 4 \mathrm{SiO}_{2}$ by holding at $700^{\circ} \mathrm{C}$ for 1 month, but some well-developed platy crystals of $4 \mathrm{PbO} \cdot \mathrm{Al}_{2} \mathrm{O}_{3} \cdot 2 \mathrm{SiO}_{2}$ were present. In fact, no sample consisting entirely of $8 \mathrm{PbO} \cdot \mathrm{Al}_{2} \mathrm{O}_{3} \cdot 4 \mathrm{SiO}_{2}$ was obtained, and this explains why the incongruent melting point was only approximated. The given temperature $\left(735^{\circ} \pm 5^{\circ} \mathrm{C}\right)$ is based in part on results of quenches and in part on the clearly defined liquidus at the intersection of the extended $8 \mathrm{PbO} \cdot \mathrm{Al}_{2} \mathrm{O}_{3} \cdot 4 \mathrm{SiO}_{2}-4 \mathrm{PbO}$.$\mathrm{Al}_{2} \mathrm{O}_{3} \cdot 2 \mathrm{SiO}_{2}$ join with the boundary for these phases.

$4 \mathrm{PbO} \cdot \mathrm{Al}_{2} \mathrm{O}_{3} \cdot 2 \mathrm{SiO}_{2}$. - The area of primary crystallization for this compound probably lies within the bounds of figure 3 . The compound was still the primary phase for a melt in the 5 percent $\mathrm{Al}_{2} \mathrm{O}_{3}$ composition series containing 81.8 percent of $\mathrm{PbO}$ but, in a melt containing 79.9 percent of $\mathrm{PbO}$, in the same series, a crystal having indices 1.92 max and $1.83 \mathrm{~min}$ was primary. 
TABLE 4.-Diffraction data for the ternary compounds *

\begin{tabular}{|c|c|c|c|c|c|c|c|c|c|c|c|c|}
\hline \multicolumn{3}{|c|}{$4 \mathrm{PbO} . \mathrm{Al}_{2} \mathrm{O}_{3} .2 \mathrm{SiO}_{2}$} & \multicolumn{2}{|c|}{$8 \mathrm{PbO} . \mathrm{Al}_{2} \mathrm{O}_{3} .4 \mathrm{SiO}_{2}$} & \multicolumn{2}{|c|}{$6 \mathrm{PbO} . \mathrm{Al}_{2} \mathrm{O}_{3} .6 \mathrm{SiO}_{2}$} & \multicolumn{2}{|c|}{$\begin{array}{l}\text { Melt } 112 \text { crystallized at } \\
720^{\circ} \mathrm{C}\end{array}$} & \multicolumn{2}{|c|}{ 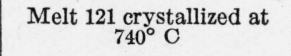 } & \multicolumn{2}{|c|}{$\begin{array}{c}\text { Melt } 128 \text { crystallized at } \\
900^{\circ} \mathrm{C}\end{array}$} \\
\hline $\begin{array}{l}\text { Estimated } \\
\text { intensity }\end{array}$ & $d$ & $h k l$ b & $\begin{array}{l}\text { Estimated } \\
\text { intensity }\end{array}$ & $d$ & $\begin{array}{l}\text { Estimated } \\
\text { intensity }\end{array}$ & $d$ & $\begin{array}{l}\text { Estimated } \\
\text { intensity }\end{array}$ & $d$ & $\begin{array}{l}\text { Estimated } \\
\text { intensity }\end{array}$ & $d$ & $\begin{array}{l}\text { Estimated } \\
\text { intensity }\end{array}$ & $d$ \\
\hline 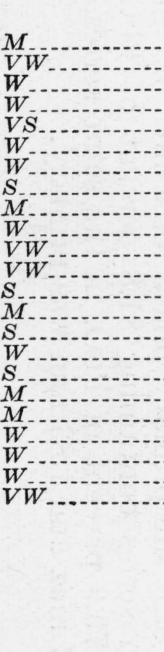 & \begin{tabular}{l|}
$A$ \\
7.7 \\
4.43 \\
3.99 \\
3.82 \\
3.22 \\
2.95 \\
2.86 \\
2.76 \\
2.46 \\
2.33 \\
2.24 \\
2.19 \\
2.12 \\
1.984 \\
1.924 \\
1.819 \\
1.763 \\
1.744 \\
1.720 \\
1.657 \\
1.635 \\
1.604 \\
1.561
\end{tabular} & $\begin{array}{l}100 \\
110 \\
111 \\
200 \\
112 \\
202 \\
210 \\
211 \\
212 \\
004 \\
302 \\
220 \\
213 \\
303 \\
312 \\
214 \\
402 \\
320 \\
321 \\
410 \\
403 \\
224 \\
412\end{array}$ & $\begin{array}{l}W \\
W \\
W W \\
V S \\
M \\
M \\
M \\
W \\
W \\
V W \\
W \\
W \\
V \\
\\
S \\
S \\
S \\
W \\
W \\
W\end{array}$ & $\begin{array}{l}A \\
9.8 \\
8.8 \\
4.30 \\
3.26 \\
3.05 \\
2.75 \\
2.61 \\
2.46 \\
2.36 \\
2.165 \\
1.992 \\
1.886 \\
1.735 \\
1.648 \\
1.573\end{array}$ & $\begin{array}{l}M \\
M \\
W \\
V S \\
S \\
V W \\
V S \\
M \\
M \\
W \\
W \\
S \\
W \\
M \\
V W \\
W \\
M \\
M \\
W \\
V W \\
W \\
W \\
W W \\
M \\
W \\
M \\
M \\
V\end{array}$ & \begin{tabular}{l|}
$A$ \\
8.6 \\
6.74 \\
4.40 \\
3.55 \\
3.30 \\
3.03 \\
2.75 \\
2.62 \\
2.37 \\
2.31 \\
2.070 \\
2.013 \\
1.963 \\
1.878 \\
1.795 \\
1.769 \\
1.711 \\
1.683 \\
1.659 \\
1.624 \\
1.566 \\
1.533 \\
1.508 \\
1.488 \\
1.439 \\
1.421 \\
1.398 \\
1.380 \\
1.361
\end{tabular} & $\begin{array}{l}M \\
W \\
W S \\
M \\
M \\
V \\
W \\
W \\
W \\
W \\
M \\
V W \\
W \\
M \\
V W \\
W \\
W \\
W \\
W \\
W \\
W \\
W \\
W \\
S^{-} \\
W \\
W\end{array}$ & \begin{tabular}{l|}
$A$ \\
9.1 \\
8.02 \\
3.45 \\
3.09 \\
2.93 \\
2.69 \\
2.61 \\
2.58 \\
2.45 \\
2.37 \\
2.34 \\
2.26 \\
2.079 \\
2.021 \\
1.916 \\
1.875 \\
1.823 \\
1.753 \\
1.729 \\
1.679 \\
1.643 \\
1.561
\end{tabular} & $\begin{array}{l}S \\
S \\
S \\
V W \\
V S \\
W \\
W W \\
M \\
M \\
M \\
M \\
V W \\
V W \\
W \\
W \\
M \\
W \\
M \\
\end{array}$ & $\begin{array}{c}A \\
10.0 \\
8.56 \\
3.70 \\
3.48 \\
3.29 \\
3.11 \\
2.88 \\
2.73 \\
2.66 \\
2.51 \\
2.40 \\
2.258 \\
2.052 \\
2.000 \\
1.905\end{array}$ & $\begin{array}{l}S \\
M \\
W \\
V W \\
M \\
W \\
V{ } \\
V S \\
M \\
V W \\
M \\
S \\
V W \\
V W \\
V W \\
V W \\
M \\
V W \\
V \\
W\end{array}$ & $\begin{array}{l}A \\
6.59 \\
5.85 \\
4.63 \\
3.94 \\
3.81 \\
3.63 \\
3.47 \\
3.29 \\
3.01 \\
2.91 \\
2.77 \\
2.56 \\
2.47 \\
2.42 \\
2.35 \\
2.31 \\
2.22 \\
2.08\end{array}$ \\
\hline
\end{tabular}

a Data by H. F. McMurdie.

b Based on hexagonal cell with $a=8.78 \mathrm{~A}$ and $c=9.48 \mathrm{~A}$. 
$4 \mathrm{PbO} \cdot \mathrm{Al}_{2} \mathrm{O}_{3} \cdot 2 \mathrm{SiO}_{2}$ forms platy crystals, which are uniaxial positive, and the indices of refraction are $\epsilon 1.94, \omega 1.93$. It melts incongruently at $837^{\circ} \mathrm{C}$ to form glass and crystals having indices of refraction 1.89 $\max$ and $1.83 \mathrm{~min}$, but the lines of the X-ray pattern were too obscure to be measured. The reverse reaction is comparatively rapid as shown by the fact that the compound composition, which at $845^{\circ} \mathrm{C}$ was 85 percent glass and 15 percent the phase of index 1.89 and 1.83 , reverted to 10 percent glass and 90 percent $4 \mathrm{PbO} \cdot \mathrm{Al}_{2} \mathrm{O}_{3} \cdot 2 \mathrm{SiO}_{2}$ after holding it for 47 hours at $830^{\circ} \mathrm{C}$.

The X-ray pattern of $4 \mathrm{PbO} \cdot \mathrm{Al}_{2} \mathrm{O}_{3} \cdot 2 \mathrm{SiO}_{2}$, crystallized at $740^{\circ} \mathrm{C}$ (table 4 ), indicates a hexagonal cell with $a=8.78 \mathrm{~A}$ and $c=9.48 \mathrm{~A}$. By calculation, this cell would contain 2 molecules and have a density of 5.2 (H. F. McMurdie).

$6 \mathrm{PbO} \cdot \mathrm{Al}_{2} \mathrm{O}_{3} \cdot 6 \mathrm{SiO}_{2}$.- This compound melts congruently at $811^{\circ} \mathrm{C}$. The crystals are prismatic, the indices of refraction are $1.89 \mathrm{max}$ and $1.79 \mathrm{~min}$, extinction parallel and elongation negative. The limited information regarding its field of primary crystallization is indicated by the diagrams (figs. 2, 3, and 4). The location of the boundary between $6 \mathrm{PbO} \cdot \mathrm{Al}_{2} \mathrm{O}_{3} \cdot 6 \mathrm{SiO}_{2}$, and the phase that is primary in melts 112 and 113 is only approximate and incomplete.

The X-ray pattern (table 4) is too complex for analysis (H. F. McMurdie).

\section{TERNARY COMPOUNDS OF UNDETERMINED COMPOSITION}

Melt 112 (fig. 2), after having been held for 2 months at $720 \pm 20^{\circ} \mathrm{C}$, had crystallized into large, platy crystals of irregular fracture having indices of refraction $\alpha 1.72, \gamma 1.765, \beta 1.728$, the character is biaxial positive, $2 v$ about $60^{\circ}$. The diffraction data are given in table 4 . The sample appeared to be one phase and the melting was fairly sharp; $760^{\circ} \mathrm{C}$ for 46 hours produced only sintering, but after 19 hours at $777^{\circ} \mathrm{C}$ and quenching, the specimen was all glass (table 3). Melt 112 contained $\mathrm{PbO}, \mathrm{Al}_{2} \mathrm{O}_{3}$, and $\mathrm{SiO}_{2}$, in the molar ratio of 12:1:20. The same crystalline phase was primary in melts 113 and 143.

Melt 121, however, has a markedly different phase in equilibrium at the liquidus. After holding a specimen at $740^{\circ} \pm 20^{\circ} \mathrm{C}$ for $3 \frac{1}{2}$ months, it apparently was over 95 percent one crystalline phase tending to platy fracture, with indices of refraction $\alpha 1.66, \gamma 1.715, \beta 1.71$, and biaxial negative in character. This melt approximates the molar composition $5 \mathrm{PbO}: \mathrm{Al}_{2} \mathrm{O}_{3}: 10 \mathrm{SiO}_{2}$, and the $\mathrm{X}$-ray pattern of the crystal phase developed at $740^{\circ} \mathrm{C}$ is described in table 4 . The crystals contained inclusions of nicely developed quartz. After the same crystallizing treatment $\left(3.5\right.$ months at $\left.740^{\circ} \pm 20^{\circ} \mathrm{C}\right)$, melt 130 was 90 percent glass and 10 percent well-developed crystals, which have the same optical properties as the crystalline phase in melt 121 .

These two phases, together with $6 \mathrm{PbO} . \mathrm{Al}_{2} \mathrm{O}_{3} \cdot 6 \mathrm{SiO}_{2}$ and the phases referred to in the discussion of the $4 \mathrm{PbO} \cdot \mathrm{Al}_{2} \mathrm{O}_{3} \cdot 2 \mathrm{SiO}_{2}$ compound, form a fringe along the "no man's land," which extends at least to the mullite and corundum boundaries. According to the information in table 3, the phase in melt 128 is present also in melts 201, 204, and 206, indicating that it may be the primary phase for a considerable portion of this superficially investigated region. Also, the results for melt 201 indicate that it may melt to form mullite and glass. This crystalline phase is tabular, has approximate indices of refraction of 1.70 max and $1.69 \mathrm{~min}$, and the diffraction data are given in table 4. 
Some of the difficulties which the explorer of this region may expect to encounter are evidenced by the time required to crystallize even partially melts such as No. 130, the volatilization of $\mathrm{PbO}$ when crystallization is attempted at temperatures in excess of the melting point of $\mathrm{PbO}$, and the poor crystal development which often makes it impossible to identify phases petrographically even after 2 or more months of heat treatment. Furthermore, it is highly probable, from index of refraction data, that solid solution takes place between a number of the compounds, and that they are (similar to $\mathrm{PbO} \cdot \mathrm{Al}_{2} \mathrm{O}_{3}$ ) unstable below their true melting point.

\section{COMPOSITIONS AS GLASSES}

Figure 5 presents diagrammatically the information obtained on indices of refraction of the melts as glasses. In those compositions containing more than about 94 percent of $\mathrm{PbO}$, the crystallization of the lead oxide was so rapid that clear glasses were not produced. All the melts appeared to be stable in air and, as is evident from their rates of crystallization, the viscosity in the molten state increased rapidly with increase in silica and in alumina.

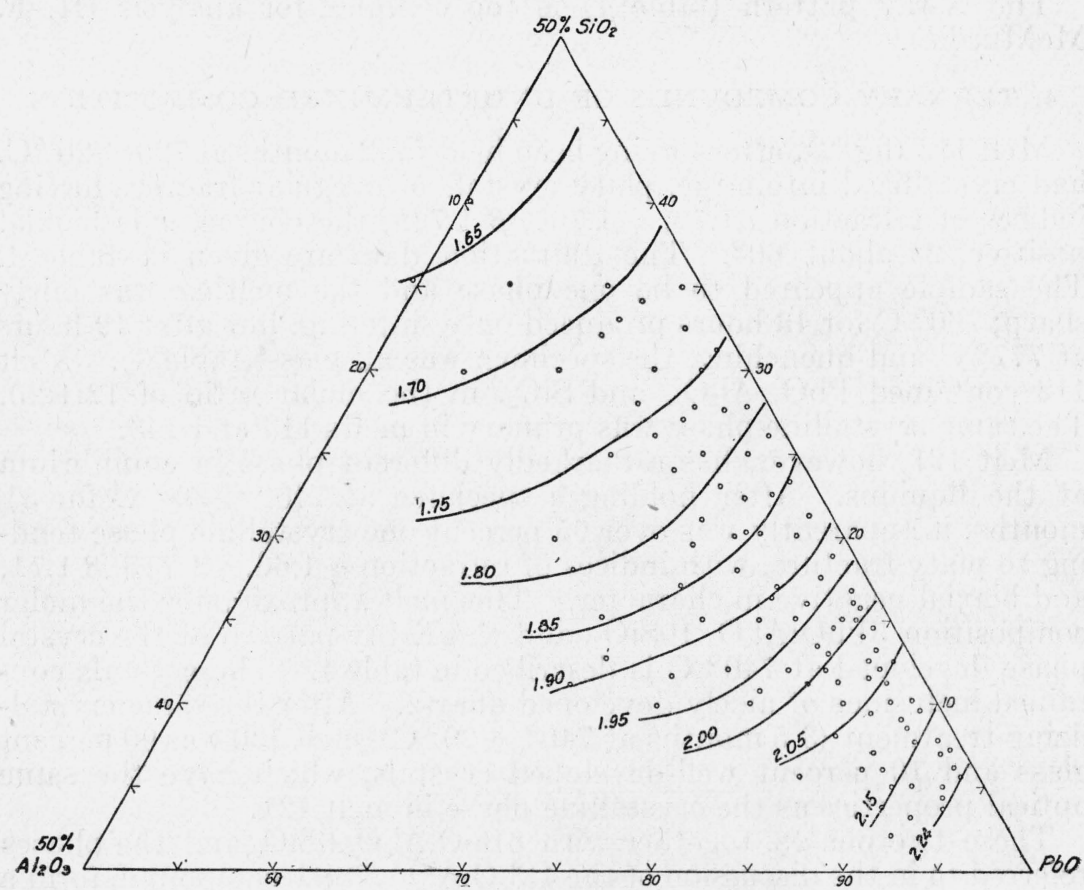

FIGURE 5.-Index of refraction of compositions as glasses. 
TABLE 5.-Composition, liquidus, and optical properties of established compounds, quintuple points, and eutectics in the systems $\mathrm{PbO}-\mathrm{Al}_{2} \mathrm{O}_{3}$ and $\mathrm{PbO}-\mathrm{Al}_{2} \mathrm{O}_{3}-\mathrm{SiO}_{2}$

COMPOUNDS

\begin{tabular}{|c|c|c|c|c|}
\hline \multirow{2}{*}{ Crystalline phases in equilibrium } & \multicolumn{3}{|c|}{ Composition (wt) } & \multirow{2}{*}{ Liquidus } \\
\hline & $\mathrm{PbO}$ & $\mathrm{Al}_{2} \mathrm{O}_{3}$ & $\mathrm{SiO}_{2}$ & \\
\hline $\begin{array}{l}\mathrm{PbO} . \mathrm{Al}_{2} \mathrm{O}_{3} \\
8 \mathrm{PbO} . \mathrm{Al}_{2} \mathrm{O}_{3} .4 \mathrm{SiO}_{2} \\
4 \mathrm{PbO} \mathrm{Al}_{2} \mathrm{O}_{3} .2 \mathrm{SiO}_{2} \\
6 \mathrm{PbO} . \mathrm{Al}_{2} \mathrm{O}_{3} .6 \mathrm{SiO}_{2}\end{array}$ & $\begin{array}{r}\text { Percent } \\
68.64 \\
83.92 \\
80.08 \\
74.34\end{array}$ & $\begin{array}{r}\text { Percent } \\
31.36 \\
4.79 \\
9.14 \\
5.66\end{array}$ & $\begin{array}{r}\text { Percent } \\
11.29 \\
10.77 \\
20.00\end{array}$ & $\begin{array}{r}{ }^{\circ} C \\
\text { About b1,000 } \\
\text { b } 735 \pm 5 \\
\text { b } 837 \\
811\end{array}$ \\
\hline
\end{tabular}

QUINTUPLE POINTS, NOT EUTECTICS

\begin{tabular}{|c|c|c|c|c|}
\hline $\begin{array}{l}2 \mathrm{PbO} . \mathrm{SiO}_{2}-8 \mathrm{PbO} . \mathrm{Al}_{2} \mathrm{O}_{3} \cdot 4 \mathrm{SiO}_{2}-4 \mathrm{PbO}_{2} \cdot \mathrm{Al}_{2} \mathrm{O}_{3} \cdot 2 \mathrm{SiO}_{2} \\
\mathrm{PbO}-8 \mathrm{PbO} . \mathrm{Al}_{2} \mathrm{O}_{3} .4 \mathrm{SiO}_{2}-4 \mathrm{Pbo}_{2} \mathrm{Al}_{2} \mathrm{O}_{3} \cdot 2 \mathrm{SiO}_{2}-\mathrm{Pl}_{2} \\
\mathrm{PbO} . \mathrm{Al}_{2} \mathrm{O}_{3}-4 \mathrm{PbO} \cdot \mathrm{Al}_{2} \mathrm{O}_{3} .2 \mathrm{SiO}_{2}-?\end{array}$ & $\begin{array}{l}85.1 \\
92.9 \\
85.7 \\
87.0\end{array}$ & $\begin{array}{r}2.3 \\
1.6 \\
6.8 \\
10.0\end{array}$ & $\begin{array}{r}12.6 \\
5.5 \\
7.5 \\
3.0\end{array}$ & $\begin{array}{r}705 \\
712 \\
837 \\
\text { About } 765\end{array}$ \\
\hline
\end{tabular}

EUTECTICS

\begin{tabular}{|c|c|c|c|c|}
\hline 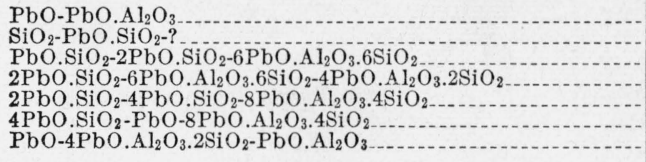 & $\begin{array}{l}94.0 \\
70.7 \\
82.6 \\
84.6 \\
89.8 \\
93.1 \\
91.2\end{array}$ & $\begin{array}{l}\text { 6. } 0 \\
\text { 1. } 0 \\
\text { 1. } 4 \\
\text { 2. } \\
\text { 1. } 2 \\
\text { 1. } \\
\text { 5. } \\
\text { 2 }\end{array}$ & $\begin{array}{r}19.3 \\
16.0 \\
13.2 \\
9.0 \\
5.8 \\
3.6\end{array}$ & $\begin{array}{r}865 \\
\text { About } 725 \\
695 \\
704 \\
694 \\
695 \\
764\end{array}$ \\
\hline Compound & \multicolumn{4}{|c|}{ Optical properties } \\
\hline $\begin{array}{l}\mathrm{PbO} . \mathrm{Al}_{2} \mathrm{O}_{3} \\
\text { 8PbO. } \mathrm{Al}_{2} \mathrm{O}_{3} .4 \mathrm{SiO}_{2} \\
\text { } \mathrm{PbO} . \mathrm{Al}_{2} \mathrm{O}_{3} .2 \mathrm{SiO}_{2}\end{array}$ & \multicolumn{4}{|c|}{$\begin{array}{l}\text { Uniaxial negative } \epsilon 1.85, \omega 1.91 \text {. } \\
\text { Index of refraction max } 2.08 \text {, min } 2.04 \text {. } \\
\text { Uniaxial positive } \epsilon 1.94, \omega 1.93 \text {. } \\
\text { Index of refraction } \max 1.89, \min 1.79 \text {. }\end{array}$} \\
\hline
\end{tabular}

a The composition is estimated.

b Incongruent melting.

\section{SUMMARY}

A report is given on the phase relations in the systems $\mathrm{PbO}-\mathrm{Al}_{2} \mathrm{O}_{3}$, and $\mathrm{PbO}-\mathrm{Al}_{2} \mathrm{O}_{3}-\mathrm{SiO}_{2}$.

It is reasonably certain that the compound $\mathrm{PbO} \cdot \mathrm{Al}_{2} \mathrm{O}_{3}$ exists, that it is unstable at temperatures in excess of about $970^{\circ} \mathrm{C}$, that it breaks. down to form corundum and glass, and that it forms a eutectic with $\mathrm{PbO}$ (at about 94 percent of $\mathrm{PbO}$ ) melting at $865^{\circ} \mathrm{C}$.

The fields of corundum and of mullite appear to dominate the ternary diagram, with the silica field as a narrow strip extending along: the $\mathrm{PbO}-\mathrm{SiO}_{2}$ side of the diagram. Three ternary compounds, and 10 quintuple points, which include 6 eutectics, were found in compositions containing over 70 percent of $\mathrm{PbO}$.

The compound $8 \mathrm{PbO} \cdot \mathrm{Al}_{2} \mathrm{O}_{3} \cdot 4 \mathrm{~S}_{1} \mathrm{O}_{2}$ melts incongruently at $735^{\circ} \pm 5^{\circ} \mathrm{C}$ to form the compound $4 \mathrm{PbO} \cdot \mathrm{Al}_{2} \mathrm{O}_{3} \cdot 2 \mathrm{SiO}_{2}$ and liquid. The latter compound melts incongruently at $837^{\circ} \mathrm{C}$ to form a ternary compound of undetermined composition, and liquid. This compound, in turn, may break down to form corundum and liquid. The third established ternary compound is $6 \mathrm{PbO} \cdot \mathrm{Al}_{2} \mathrm{O}_{3} \cdot 6 \mathrm{SiO}_{2}$, which melts congruently at $811^{\circ}$ C. The liquidus temperatures of the quintuple points range from $694^{\circ}$ to $837^{\circ} \mathrm{C}$. Three of the eutectıcs melt within $1^{\circ}$ of $695^{\circ} \mathrm{C}$ 
and within 0.2 percent of 1.2 percent of $\mathrm{Al}_{2} \mathrm{O}_{3}$ in composition; their $\mathrm{PbO}$ contents are 82.6 percent, 89.8 percent, and 93.1 percent, respectively.

A considerable portion of the system remains to be investigated. The indications are that at least four more ternary compounds exist in addition to those identified.

In addition to the above, the melting point of $\mathrm{Al}_{2} \mathrm{O}_{3}$ was redetermined and found to be $2,035^{\circ} \pm 10^{\circ} \mathrm{C}$, and a chart is presented to show the indices of refraction of the various compositions as glasses.

Washington, July 19, 1943. 